研究課題別評価書

1. 研究課題名

機能性 RNA による代謝調節の分子基盤の解析

2. 氏名

稲田 利文

3. 研究のねらい

1. 代謝ストレスに応答した遺伝子発現制御と新規機能性RNAの探索。我々は、環境応答 の代表例である大腸菌グルコース効果の分子機構の解析を行い、以下を明らかにした。 1) 一般的に受け入れられているcAMPによる制御ではなく、グルコースによる他の糖 の輸送阻害がグルコース応答の主因である。2）解糖系中間産物の蓄積という代謝ス トレスに応答して機能性RNAが発現し、グルコーストランスポーターの発現が転写後段 階で抑制される。本研究では、この研究を真核生物で発展させ、解糖系中間産物の蓄 積という代謝ストレスに応答した遺伝子発現、特に機能性RNAを介した翻訳制御につい て明らかにすることを目標とした。具体的には、我々が開発した迅速なポリソーム解 析法を中心に、解糖系代謝遺伝子の欠損変異株における代謝遺伝子の発現を、翻訳段 階での制御を中心に解析し、代謝産物の変化情報に基づく新たな細胞機能の解明を目 指した。近年、代謝産物がRNAに直接結合して構造を変化させ、翻訳段階で遺伝子を制 御することが原核生物で明らかになり、リボスイッチという概念が提唱されている。 リボスイッチは主にシス因子として機能し、代謝産物への結合を介して下流の遺伝子 の翻訳開始効率を制御している。真核生物には同様のRNA分子は同定されていなかった ため、本研究により特定の代謝産物結合する真核生物におけるリボスイッチが明らか になることが期待された。

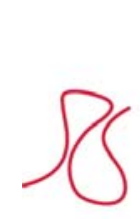

非活性型

(1)

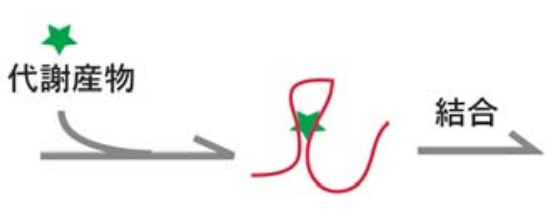

活性型

(2)

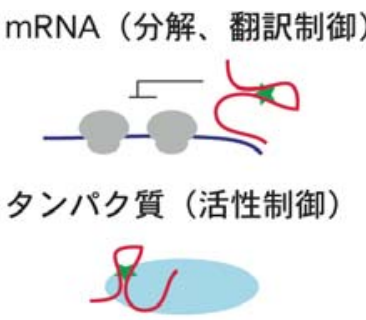

(3)

図 1 真核生物におけるリボスイッチの概念図

非活性型の機能性 RNA(1)が代謝産物と結合し、活性化型の構造(2)に変換する。活性 型 RNA が標的 mRNA の 3'UTR と相補対を形成し、翻訳が抑制される（3)）。またはタ ンパク質に結合して、活性を制御する。

2. 遺伝子発現の正確性を保証する品質管理機構の解析。遺伝情報の担い手であるmRNA自 身が正確に合成され、正しく局在し制御を受けることは、生命現象の基礎であり極めて重要 である。一方DNA変異等に起因する異常mRNAは、生命活動を担うタンパク質の発現量や活 性の低下を介して、様々な悪影響を細胞にもたらたす可能性がある。最も劇的なアミノ酸配 列の変化を引き起こす変異は、塩基の欠失や挿入による読み枠のずれ(フレームシフト変 異)であり、かつ多くの場合には正常な位置より上流で翻訳が終結する。また、強制的に翻 訳を終結させるナンセンス変異や終止コドンを失った場合にも、異常な長さのタンパク質が発 現される。これらの変異の結果として共通する性質は、終止コドンの位置の異常による翻訳 終結の異常であり、その遺伝子産物が発現した場合には正常なタンパク質の活性を阻害す 
る可能性がある。しかしながら、細胞の持つ品質管理機構によって異常タンパク質の発現が 強く抑制され、細胞は生存可能となる。ナンセンス変異を持ったmRNAは、NMD (nonsense-mediated decay; ナンセンス変異依存分解系) と呼ばれる特異的分解系によって 速やかに分解される。
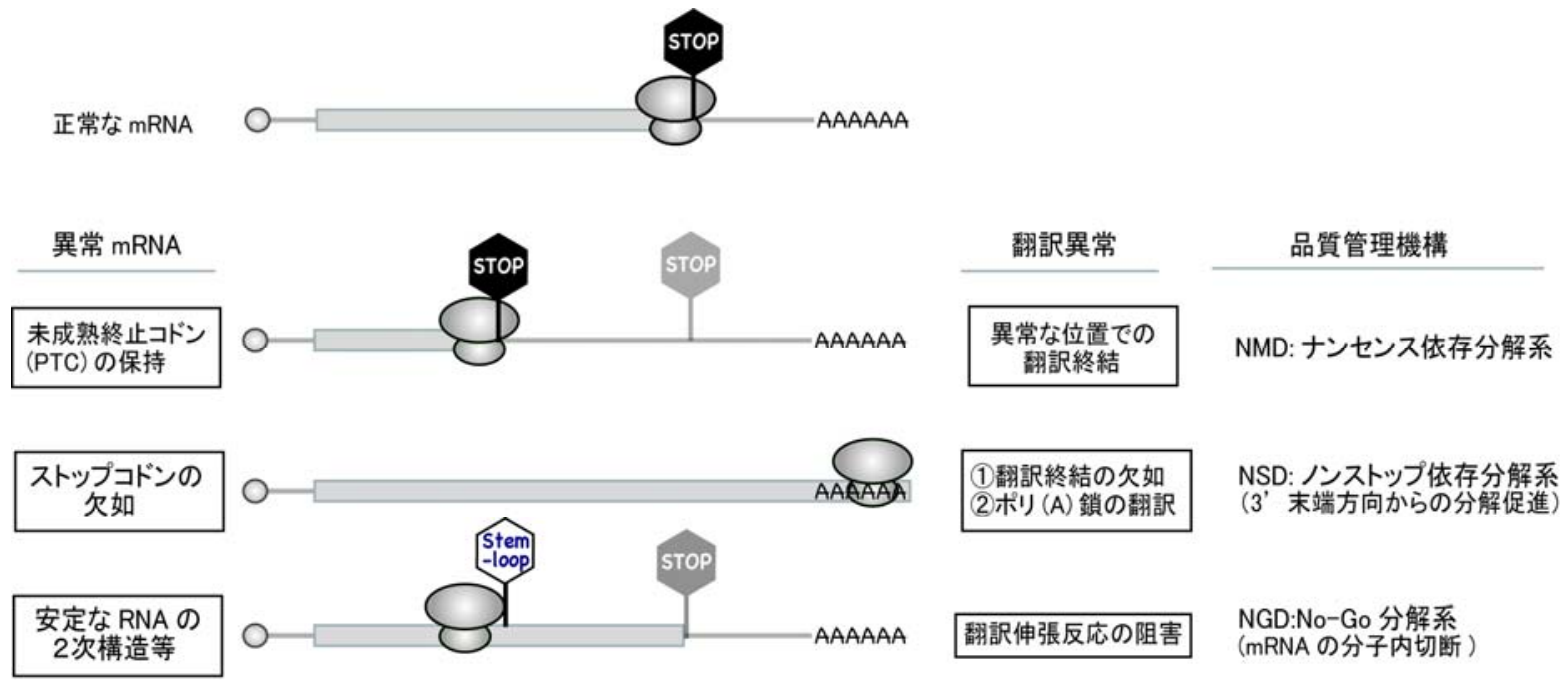

図2 真核生物における mRNA 品質管理機構

ナンセンス変異を持った mRNA は、NMD (nonsense-mediated decay;ナンセンス変異 依存分解系) と呼ばれる特異的分解系によって速やかに分解される。また終止コドン を持たない異常 mRNA は、NSD (nonstop decay; ハンストップ分解系)によって分解され る。また翻訳伸長阻害に伴って mRNA の分子内切断 NGD (No-Go Decay) が引き起こ される。

終止コドンの位置が異常である mRNA として、最も極端なケースは終止コドン自体を含まない mRNA である。最近真核生物におけるノンストップ mRNA 特異的な分解系 NSD (nonstop decay; ハンストップ分解系)が発見された。我々は、ハンストップ mRNA の翻訳と分解について解析し、 ハンストップ mRNA 由来の翻訳産物が非常に低いレベルに抑制されることを最近明らかにした。 また、リボソームの動態を解析することにより、リボソームが mRNA の 3' 端で停滞する結果、ノ ンストップ mRNA の翻訳効率が顕著に低下することを明らかにした。この品質管理機構におけ る翻訳開始以降の段階での新たな制御機構の分子メカニズムを明らかにすることを目標に解 析を行った。

4. 研究成果

1. 代謝ストレスに応答した遺伝子発現制御と新規機能性RNAの探索。

解糖系遺伝子を始めとする多数の代謝系変異株の作成ならびに確認と、アレイを用い た網羅的な翻訳効率の解析条件を確立した。アレイによって候補として挙げられた遺伝 子について、網羅的なポリソーム解析を行い、ポリソーム中の mRNA の分布が変化するか についての解析を行い、候補遺伝子を探索した。代謝遺伝子欠損変異株における遺伝子 発現制御については、翻訳制御に関する新たな知見は得られなかったため、mRNA 品質管 理機構等の発現制御機構と解糖系などの代謝経路との関係の解明が今後の課題である。

\section{2. 遺伝子発現の正確性を保証する品質管理機構の解析。}

現在明らかになっている mRNA 品質管理機構は、リボームによって翻訳終結の異常を認 識し、mRNA の分解を促進する機構である。例えば、ナンセンス変異を持った mRNA は、NMD (nonsense-mediated decay；ナンセンス変異依存分解系）と呼ばれる特異的分解系によ 
って速やかに分解される。また終止コドンを持たない異常 mRNA は、NSD (nonstop decay ; ノンストップ分解系）によって分解される。また翻訳伸長阻害に伴って mRNA の分子内切 断が引き起こされる。しかしながら、細胞内に存在する様々な異常 mRNA 由来の遺伝子産 物の発現抑制機構の全体像は明らかでない。特に、異常な mRNA の翻訳抑制機構や異常タ ンパク質の安定性制御の役割は全く明らかでなかった。我々は、遺伝子発現の正確性を 保証する品質管理機構の全体像を明らかにする目的で、代表的な異常 mRNA であるノンス トップ mRNA とナンセンス変異をもつ mRNA における翻訳抑制と異常タンパク質分解機構 についても解析を行った。

\section{【結果】}

ノンストップmRNAにおける翻訳抑制と 異常タンパク質分解機構について解析を 行った結果、通常翻訳されないポリ(A) 鎖 が翻訳され、1) 合成中のポリリジンとリ ボソームとの相互作用による翻訳アレス ト（一時停止）と、2) プロテアソームに よる異常タンパク質の速やかな分解、を見

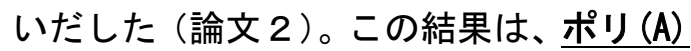
鎖の翻訳自体が、多段階での発現抑制機構 を作動させ、品質管理機構において必須な 役割を果たすことを初めて明確に示し、真 核生物のmRNAの普遍的な修飾であるポリ (A) 鎖が、翻訳開始とmRNA安定性制御に加 えて、品質管理機構にも重要な役割を果た すことを世界に先駆けて明らかにした。
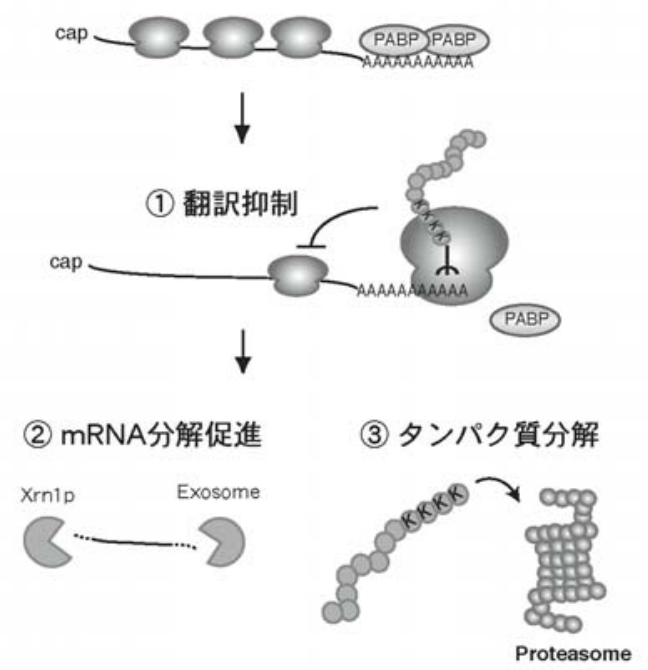

ノンストップmRNA品質管理機構におけるポリ(A)鎖の新たな役割

\section{【研究の意義と波及効果】}

(1) ポリ (A) 鎖の新しい役割の発見

ポリ (A) 鎖は真核生物のmRNAの普遍的な修飾であり、ポリ (A) 結合因子 (PABP) を介して、 1) 翻訳開始の促進と、2） mRNA 安定化に極めて重要な役割を果たすことは広く知られ ている。この研究により、正常なmRNAでは決して翻訳されることがないポリ (A) 鎖が、終 止コドンを持たない異常mRNAのみで翻訳されることで、翻訳伸張阻害とタンパク質の分

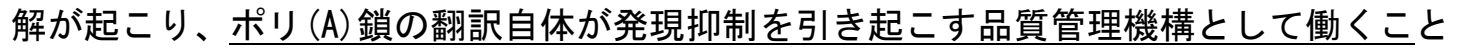
が明確に示された。ポリ (A) 鎖の新しい機能を明らかにした点で、独創性の高い研究であ ると考えられる。

\section{（2）品質管理機構の新しい機構の発見}

遺伝子発現の正確性を保証するmRNA品質管理機構の解析は、世界的にもmRNA分解のみ が解析されてきた。異常タンパク質の認識と分解機構の解明を目的とした本研究は、mRNA 品質管理機構に全く新しい視点をもたらした。さらに翻訳中の遺伝子産物の異常を認識 し、積極的に分解する機構の分子実体が明らかになったことは、品質管理機構にとどま らず、遺伝子発現制御機構全体の理解に大きな影響を与えたものと考えられる。

\section{（）新生ポリペプチド鎖による翻訳伸長制御の普遍性}

さらにポリ (A) 鎖由来の連続したリジン残基のみでなく連続したアルギニン残基によ っても翻訳アレストが引き起こされることが明らかとなり、塩基性新生ポリペプチド鎖 の持つ正の電荷とリボソームトンネルを形成するリボソーマルRNAの負の電荷の間の静 電的相互作用による翻訳抑制機構が示唆された。以上の結果は、限定された例のみが報 告されている合成途中の新生ポリペプチド鎖とリボソームトンネル（合成途中の新生ポ 
リペプチド鎖が通るリボソーム中のトンネル）との相互作用による翻訳制御が普遍的で あることを強く示唆する点で、遺伝子発現制御研究全体に大きな影響を与えるものと考 える。

\section{5. 自己評価}

正確な遺伝子発現を保証し、異常な RNA とタンパク質を速やかに代謝する品質管理シス テムに関して、独自の視点から新たな知見を得たと考える。品質管理機構の解析は、ヒト の遺伝病の主要な原因変異であるナンセンス变異が原因で引き起こされる遺伝病の治療法 開発に直結しており、今後さらに解析を進めたい。これらの新しい品質管理の分子機構の 解明は、治療薬開発の基盤であるが、ほとんど明らかに出来ておらず、今後の大きな課題 である。また、mRNA 品質管理機構に対する細胞内代謝環境の影響に関する研究が不足して おり今後の課題である。

\section{6. 研究総括の見解}

遺伝子産物の品質管理や分解機構に関する進渉が見られ、non-stop RNA 産生抑制、ポリ塩 基性アミノ酸による翻訳抑制、プロテアソーム系での異常タンパク質の処理のメカニズムを明らか にした。翻訳段階での異常タンパク質、mRNA の分解·制御の成果は高く評価できる。ただし、当 初の計画の代謝産物と mRNA との直接的作用による転写制御に関しては、殁ど進展は見られな かった。今後は代謝の機能制御という視点からの研究を推進することを意識して欲しい。

\section{7. 主な論文等}

(A)さきがけの個人研究者が主導で得られた成果

(1) 論文 (原著論文) 発表 * Corresponding author

1. Ito-Harashima, S., Kuroha, K., Tatematsu, T. and Inada, T.* Translation of poly(A) tail plays crucial roles in nonstop mRNA surveillance via translation repression and protein destabilization by proteasome in yeast. Genes Dev. 21: 519-524. (2007)

2. Dimitrova, LN., Kuroha, K., Tatematsu, T. and Inada, T.* Nascent Peptide-dependent Translation Arrest Leads to Not4p-mediated Protein Degradation by the Proteasome. J. Biol. Chem. in press

3. Kuroha, K., Horiguchi, N., Aiba, H. and Inada, T.* Analysis of nonstop mRNA translation in the absence of tmRNA in E. coli. Genes to Cells. in press

(2) 特許

なし

(3) 著書

1. 稲田利文「mRNA の品質管理機構」

化学と生物 44:589-595. (2006)

2. 稲田利文「正常と異常を識別する品質管理機構」

蛋白質核酸酵素増刊『遺伝暗号解読 40 周年』51:842-843. (2006)

3. 稲田利文「mRNA 品質管理機構における poly(A)鎖の新たな役割」

蛋白質核酸酵素増刊『RNA と生命』51: 2549-2555. (2006)

4. 稲田利文、塩見春彦編

無敵のバイオテクニカルシリーズ『RNA 実験ノ一ト』羊土社（2008）

5. 稲田利文「mRNA の動態とプロテアソーム」

実験医学増刊『タンパク質の分解機構』26: 237-241. (2008) 
(4) 招待講演

1. Toshifumi Inada 「Novel roles of a poly $(A)$ tail in nonstop mRNA surveillance system」 RNA2006Izu 平成18年12月

2. 稲田利文「mRNA 品質管理と翻訳制御」 日本分子生物学会シンポジウム 平成18年12月

3. 稲田利文「mRNA 品質管理と疾患」 Wako ワークショップ 平成19年11月

4. 稲田利文「遺伝子発現の正解性を保証する mRNA 品質管理機構」 酵母合同シンポジウム 2008 酵母の挑戦 平成20年6月

(5)学会発表 (国際)

1. 平成19年 6 月 The Ribosomoe, MA, USA

2. 平成19年 9月 Translational Control, EMBL, Germany

(6) ワークショップ・学会オーガナイザー

1. 平成18年12月 日本分子生物学会シンポジウム「mRNA 品質管理と翻訳制御」

2. 平成19年 7月 第9回日本 RNA 学会年会(名古屋)

3. 平成20年10月 日英最先端シンポジウム(UK-JFOS2008)

4. 平成20年12月 日本分子生物学会シンポジウム「拡大する品質管理の概念」

(B)その他の主な成果

(1) 論文 (原著論文) 発表

1. Nukazuka, A., Fujisawa, H., Inada, T., Oda, Y. and Takagi, S. Semaphorin controls epidermal morphogenesis by stimulating mRNA translation via eIF2a in Caenorhabditis elegans. Genes Dev. 22: 1025-1036. (2008)

2. Endo, A., Matsumoto, M., Inada, T., Yamamoto, A., Nakayama, K., Kitamura, N. and Komada, M. Nucleolar structure and function are regulated by the deubiquitinating enzyme USP36. J. Cell Sci. 122: 678-686. (2009) 